\title{
Health impact of living near an abandoned mine - Case study: Jales mines
}

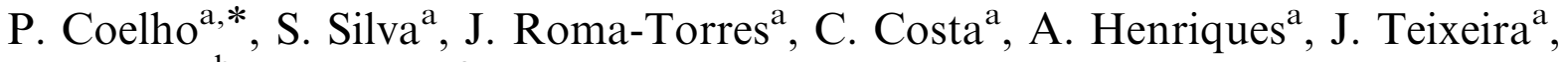 \\ M. Gomes ${ }^{\mathrm{b}}$, O. Mayan ${ }^{\mathrm{a}}$ \\ ${ }^{a}$ National Institute of Health, Centre of Environmental and Occupational Health, Praça Coronel Pacheco, \\ 15, 4050-453 Porto, Portugal \\ ${ }^{\mathrm{b}}$ Nurse School, Bragança, Portugal
}

\begin{abstract}
The activities of mining exploitation in Campo de Jales were performed in an uncontrolled way and gave rise to serious environmental contamination: rubbish depositories have been accumulated with no treatment or maintenance. An investigation developed around Jales Mine showed the existence of some chemical impact originated from the waste produced during mining activities. Some "black spots" for a wide suite of heavy metals were determined in stream sediments and alluvium drained from Jales tailings, which could constitute hazard factors for the area and potential danger for public health. The main objective of this study is to know the effects on health caused by this environmental contamination. It is a case-control study, where two populations - from Campo de Jales and Vilar de Maçada - were compared. They both have very similar living conditions, and were inquired about health issues and screening for lead and cadmium exposure. The results point out to higher prevalence of irritating symptomatology in the mucous of the eyes and respiratory system as well as higher lead and cadmium exposure in the Campo de Jales population.
\end{abstract}

(C) 2007 Elsevier GmbH. All rights reserved.

Keywords: Mining; Heavy metals; Environmental contamination

\section{Introduction}

Jales mining belt site is an inactive gold mining area located in the Vila Real district, in the Northeast of Portugal. The site encompasses the abandoned industrial complex and a village (Campo de Jales) with a residential capacity of approximately 900 people. Industrial exploration of Jales' mines was abandoned in 1992.

\footnotetext{
*Corresponding author. Tel.: + 351222046405 ; fax: +351222046409

E-mail address: pcscoelho@gmail.com (P. Coelho).
}

Mining activities had an important role for local and national economy, however they were performed in an uncontrolled way, gave rise to great soil erosion and serious environmental contamination by contaminating water (surface water - the river Tua - and ground water), soil and wetland sediments, and biota. The main pollutants were heavy metals, with elevated concentrations of manganese, cadmium, lead and arsenic (Oliveira and Àvila, 1995) being found. In face of these results a public water supply system was installed and the community was advised not to use private wells. However, there remain other potential exposure pathways for the residents, namely: inhalation of particles, 
contact with dust and the potential consumption of contaminated food (local vegetables and animals).

The lack of reliable information on health impact related to the contamination of the site draw attention to the need of a community health study. The present case-control study aims to investigate health effects and concerns of the individuals, and cadmium and lead exposure associated with environmental contamination in Campo de Jales.

\section{Material and methods}

\section{Study subjects}

Health effects and cadmium and lead exposure were studied among Campo de Jales inhabitants. A control group was formed by people living in Vilar de Maçada, located about $45 \mathrm{~km}$ northeast of Campo de Jales. This village is not in the vicinity of a mine complex or other industrial units, and is similar to Campo de Jales, with the same geological, economical and demographic characteristics, as well as lifestyle. Inclusion criteria for the study population were: subjects had never worked in mines or other activities with potential exposure to heavy metal and their age was 15 years or older. The study population consisted of 229 cases and 234 controls.

\section{Health impact assessment}

The study was developed in accordance with the Helsinki declaration (guidelines in biomedical research involving human subjects) (World Medical Association, 2004). The health impact evaluation included the study of symptoms experienced by people, their health concerns, and the evaluation of cadmium and lead exposure levels.

\section{Health effects and concerns assessment}

To characterise health status and concerns we analysed the information on prevalence of symptoms, prevalence of diseases and health concerns. Information was collected by a door-to-door interview, using a questionnaire. The questionnaire elicited information about: demographic characteristics, education, life style, namely tobacco and alcohol consumption, professional history, diseases of the individual and of family members; a group of questions about symptoms (respiratory, digestive, sensorial and neurological, and irritation of eyes), and one question about health concerns (evaluated by the periodicity of visits to the family physician for medical surveillance).

\section{Cadmium and lead exposure}

Exposure to cadmium and lead was evaluated by biological monitoring using as biomarkers cadmium and lead levels in blood. Cadmium and lead concentrations in blood were analysed using a graphite furnace atomic absorption spectrophotometer with Zeeman background correction.

\section{Statistical analysis}

Descriptive statistics (mean, standard deviation (SD), median and range) were used to describe blood cadmium and lead levels. Statistical analysis of differences in blood cadmium and lead levels in the two groups (cases and controls) was carried out by Student's $t$-test. All of the collected information was analysed by logistic regression. Odds ratios $(95 \%$ confidence interval) were calculated to evaluate health concern. All analyses were performed with an SPSS statistical package (version 10.5) (SPSS Inc., Chicago, IL, USA). The level of significance was set at $p<0.05$.

\section{Results}

We checked the homogeneity between the two groups and no significant differences were found in tobacco consumption, eating habits and leisure activities. A significant difference was found in alcohol consumption, with more heavy drinkers in the control group. Table 1 list the symptoms for which we found significant

Table 1. Symptoms prevalence

\begin{tabular}{lllll}
\hline Symptoms & Prevalence (\%) & & $\begin{array}{l}\text { Odds ratio cases } \\
\text { compared to controls }\end{array}$ & $\begin{array}{l}95 \% \text { confidence } \\
\text { intervals }\end{array}$ \\
\cline { 2 - 4 } & Cases & Controls & \\
\hline Shortness of breath & 16.5 & 14.8 & 2.002 & $1.71-4.99$ \\
Cough & 17.4 & 13.8 & 2.133 & $1.24-3.19$ \\
Sneeze & 21.3 & 14.0 & 3.542 & $2.32-5.41$ \\
Hoarse, dry throat & 11.9 & 9.2 & 2.010 & $1.43-3.09$ \\
Itching, irritation of eyes & 24.1 & 11.9 & 2.533 & $3.59-8.70$ \\
Lost of smell (anosmia) & 5.1 & 2.8 & 2.561 & $1.11-5.45$ \\
\end{tabular}


Table 2. Blood cadmium levels $(\mu \mathrm{g} / \mathrm{l})$

\begin{tabular}{llllll}
\hline & Mean & SD & $\begin{array}{l}\text { 95\% Confidence limits } \\
\text { for mean }\end{array}$ & Median & Range \\
\hline Campo de Jales & 0.84 & 0.58 & $0.72-0.96$ & 0.79 & $0.15-2.01$ \\
Vilar de Maçada & 0.65 & 0.30 & $0.59-0.71$ & 0.63 & $0.14-1.85$ \\
\hline
\end{tabular}

Table 3. Blood lead levels $(\mu \mathrm{g} / \mathrm{dl})$

\begin{tabular}{llllll}
\hline & Mean & SD & $\begin{array}{l}95 \% \text { Confidence limits } \\
\text { for mean }\end{array}$ & Median & Range \\
\hline Campo de Jales & 9.52 & 3.90 & $8.74-10.30$ & 8.80 & $3.4-23.6$ \\
Vilar de Maçada & 7.73 & 2.87 & $7.16-8.31$ & 7.65 & $1.8-17.5$ \\
\hline
\end{tabular}

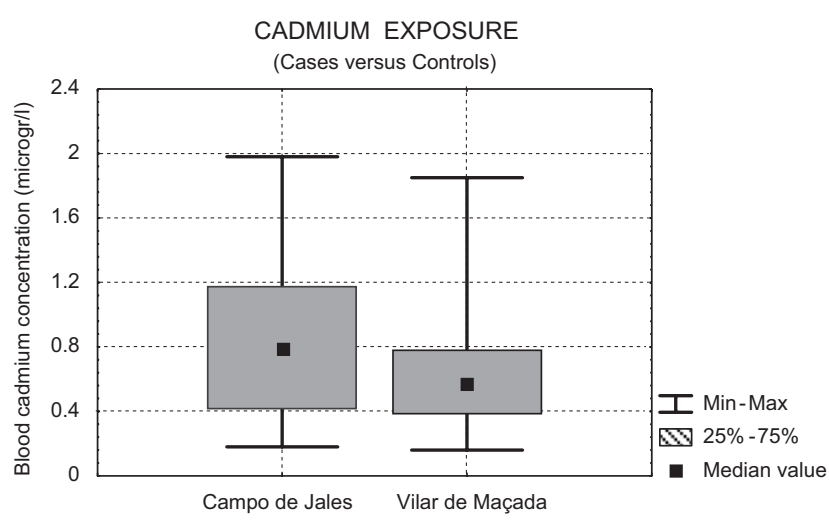

Fig. 1. Blood cadmium concentrations.

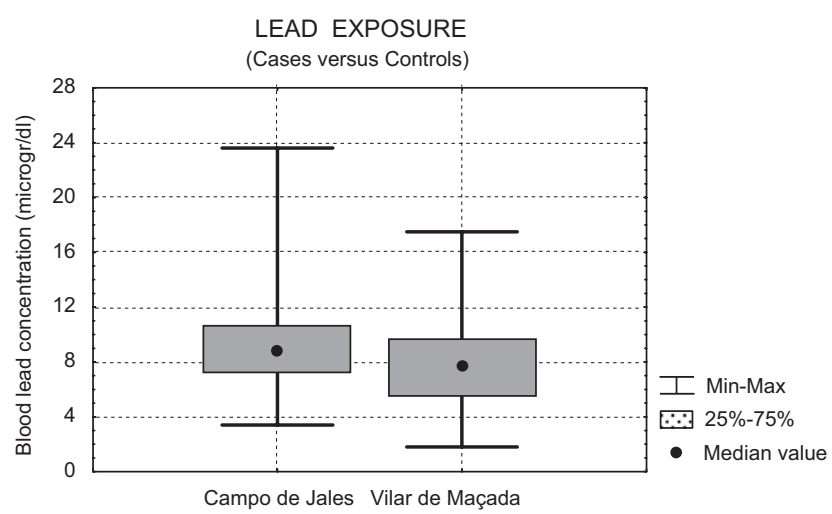

Fig. 2. Blood lead concentrations.

differences in prevalence data between the two groups. Results showed that odds ratio for having more respiratory symptoms and lost of smell (anosmia) doubled for inhabitants of Campo de Jales. Also, odds ratio of suffering of eye irritation was more than five times higher for those living in Campo de Jales.
Campo de Jales' inhabitants reported more cases of respiratory disease (11 vs. 3 ) and cancer cases in family members (5 vs. 3 ) than those of Vilar de Maçada. Tables 2 and 3 show the results of cadmium and lead levels in the blood, separated by groups. Results of blood cadmium and lead concentrations portrayed a significantly higher exposure $(p=0.000)$ for people living in Campo de Jales (Figs. 1 and 2).

\section{Discussion}

The results of this study showed that contamination on the site had an impact on health of the community. The inhabitants of Campo de Jales give evidence of a higher exposure to cadmium and lead. However, results showed that exposure levels were lower than they had been predicted, as based on the site contamination assessment that took place in 1997. This could be explained by the preventive measures that were taken since then - installation of a public water supply system, and water quality surveillance. In comparison with the control group, complaints are reported to a significantly higher degree by subjects located in the vicinity of abandoned Jales mines, with a higher prevalence of eye irritation and mucous and respiratory symptoms being denounced. These symptoms could be originated by dust emanating from waste piles. On the other hand, sensorial symptoms (anosmia), for which a higher prevalence was also found, were correlated with blood cadmium levels. The results also point out for more respiratory diseases and cancer cases within Campo de Jales.

Our results are in accordance with other studies developed on health impact of living on contaminated sites. Mining sites usually envelope soil contamination and a higher exposure to heavy metals for the population residing in the area (Alonso et al., 2001; Paoliello et al., 2002). 
A restoration programme is now ongoing, until 2010, which includes the following actions: stabilisation of old mine buildings for historical interpretation, procedures for closing mine addicts and shafts, procedures for containing mine wastes and bioremediation. Some measures have been taken in order to diminish soil erosion and dispersion of contaminants to the surroundings (Bleeker et al., 2003).

\section{References}

Alonso, E., Cambra, K., Martinez, T., 2001. Lead and cadmium exposure from contaminated soil among residents of a farm area near an industrial site. Arch. Environ. Health 56 (3), 278-282.
Bleeker, P., Teiga, P., Santos, M., de Koe, T., Verkleij, J., 2003. Ameliorating effects of industrial sugar residue on the Jales gold mine spoil (NE Portugal) using Holcus lanatus and Phaseolus vulgaris as indicators. Environ. Pollut. 125 (2), 237-244.

Oliveira, J., Àvila, P., 1995. Avaliação do impacto químico ambiental provocado por uma exploração mineira. Um caso de estudo na mina de Jales. Estudos, Notas e Trabalhos. IGM, pp. 25-50.

Paoliello, M., De Cpitani, E., Cunha, F., Matsuno, T., Carvalho, M., 2002. Exposure of children to lead and cadmium from a mining area of Brazil. Environ. Res. 88 (2), 120-128.

World Medical Association, 2004. Declaration of Helsinki: ethical principles for medical research involving human subjects. J. Int. Bioethique 15 (1), 124-129. 